\title{
Formation of the strategy of management of innovation and investment activity of the enterprise
}

\author{
Elena Minaeva ${ }^{1}$, Vera Lastochkina $^{2}$, Valery Gusev ${ }^{3}$, Alexander Fadeev ${ }^{4}$ and Lyubov \\ Manukhina ${ }^{5, *}$ \\ ${ }^{1}$ Russian State University of Justice, 69, Novocheremushkinskaya street, 117418, Moscow, Russia \\ ${ }^{2}$ Moscow Aviation Institute, Volokolamskoe highway, 4, 125993, Moscow, Russia \\ ${ }^{3}$ Moscow state University of technology and management. K.G. Razumovsky, Zemlyanoy Val street, \\ 73, 109004, Moscow, Russia \\ ${ }^{4}$ Bauman Moscow State Technical University, 2nd Baumanskaya street, 5/ 1,105005, Moscow Russia \\ ${ }^{5}$ Moscow State University of Civil Engineering, Yaroslavskoe sh., 26, 129337, Moscow, Russia
}

\begin{abstract}
The purpose of this study is to develop theoretical aspects and practical approaches to the formation of a strategy for managing the innovation and investment activity of an industrial enterprise at various stages of its life cycle. The article reveals the actual scientific and practical features of innovative and investment activities of economic entities, suggests a methodical approach to determining the probability of transition to an innovative type of enterprise development, developed an algorithm for determining the most optimal strategy for innovation and investment activity based on analysis of the parameters of its predictable stability. The result of the study is the formation of an approach to the analysis and evaluation of the effectiveness of implementing the strategy of innovation and investment development of the enterprise at various stages of its life cycle.
\end{abstract}

\section{Introduction}

Modern innovative activity of industrial enterprises is reduced to adaptation to the current market situation through the introduction of low-efficiency point-based innovations and is characterized by a lack of innovation strategy of the enterprise that would allow to create and implement large-scale innovations of a different type and form capable of generating high added value.

The possibility of moving to an innovation-oriented way of development of an industrial enterprise depends to a large extent on the degree to which the implemented innovations are provided with the necessary volume of investment resources. The reorientation of the economic system to innovative activity requires attracting in necessary volumes both external and internal investments, different in types and forms. At the same time, it should be noted that innovative and investment processes at the enterprise need to

\footnotetext{
*Corresponding author: 4804107@mail.ru
} 
be considered comprehensively, based on logically selected and economically justified indicators of the economic entity's performance, with the obligatory consideration of the synergetic effect [1].

In order to innovate the economy, the author proposed to consider the enterprise as a complex economic system that is in the conditions of the need to implement innovative transformations for the purposes of successful economic and economic functioning, taking into account the attraction of investments of all types and forms to ensure sustainable development at all stages of the life cycle. Thus, investment support should not only facilitate effective search and introduction of innovations, but also be a fundamental aspect of the mechanism that allows accelerating the process of generating innovations both at the enterprises themselves and outside it [2].

\section{Materials and Methods}

Further study of the problems of evaluation and analysis of innovation and investment reforms made it possible to conclude that the effectiveness of these reforms at the macro and meso levels will be directly dependent on the economic and social effects achieved.

$$
\mathrm{Ef}_{\text {invest }}^{\text {innov }}=\mathrm{Ef}_{\text {econ }}+\mathrm{Ef}_{\text {soc }}
$$

where $\mathrm{Ef}_{\text {invest }}^{\text {innov }}$ - efficiency of innovation-investment transformation depending on the level of analysis (macro- or meso-level);

$\mathrm{Ef}_{\text {econ }}$ - the achieved economic effect from innovative transformations;

$\mathrm{Ef}_{\text {soc }}$ - the social effect achieved from innovative transformations.

In turn, social and economic effects can be represented in the form of the following dependencies:

$$
\left\{\begin{array}{l}
\mathrm{Ef}_{\mathrm{econ}}=\frac{\partial \mathrm{B}}{\partial t}+\frac{\partial \mathrm{Inc}}{\partial t} \\
\mathrm{Ef}_{\mathrm{soc}}=\frac{\partial \mathrm{B}}{\partial t}+\frac{\partial \mathrm{Inc}}{\partial t}+\frac{\partial \text { Prog }}{\partial t}+\frac{\partial \mathrm{E} c o l}{\partial t}
\end{array}\right.
$$

where $\frac{\partial \mathrm{B}}{\partial t}, \frac{\partial \mathrm{Inc}}{\partial t}, \frac{\partial \operatorname{Prog}}{\partial t}, \frac{\partial \mathrm{E} c o l}{\partial t}$ - change, accordingly, budgetary efficiency, growth of incomes of subjects of innovative and investment activity, acceleration of NTP, improvement of ecological situation.

Substituting the data of the system of equations (2) into equation (1), we obtain the following relationship:

$$
\mathrm{Ef}_{\text {invest }}^{\text {innov }}=2 \cdot\left(\frac{\partial \mathrm{B}}{\partial t}+\frac{\partial \mathrm{Inc}}{\partial t}\right)+\frac{\partial \mathrm{Prog}}{\partial t}+\frac{\partial \mathrm{E} c o l}{\partial t}
$$

As a measure of the economic effect of innovation and investment reforms at enterprises at macro and meso levels, it is suggested to understand the total value of changes in budget efficiency, incomes of subjects of innovation and investment activity, scientific and technological progress and environmental conditions.

Analysis of the economic content of the macro- and mesic environment in the space of which the enterprise is located has made it possible to determine the requirements for the parameters of the further development of the economic entity, the systemic implementation 
of which will allow management to reduce the amount of necessary investments necessary for the innovative development of the business structure:

- intensification and diversification of economic development, increasing macro and mesoeconomic indicators;

- the growth of the value of the human resource as a source of innovative ideas, and also as a potential consumer;

- increasing the role of science and education;

- development of information and communication technologies;

- the development of high-tech industries and the increase in their share and the specific economic weight in the overall structure of the national economy.

Thus, the innovative activity of the business entity will involve not only the introduction of product, technological or managerial innovations, but also the training and development of human resources that form special behavioral models that fulfill the desire for innovative improvement [3].

Further study of the economic and economic activities of the enterprise made it possible to divide the factors of innovative provision of systemic transformations of an economic entity according to the institutional feature and the degree of activity (Figure 1).

The study proposed to consider four classification types of factors that form the conditions for transition to an innovative type of enterprise activity: external active (AX), external passive (AY), internal active (BX), internal passive (BY). In the author's opinion, the proposed classification covers the whole multitude of existing innovative incentives, while allowing to take into account the different nature of sources of the formation of factors of innovation development.

Guided by the developed classification, the next step in the study suggested to consider the indicator of the probability of implementing innovative transformations of the economic entity in the form of a matrix of factors different in the classification type.

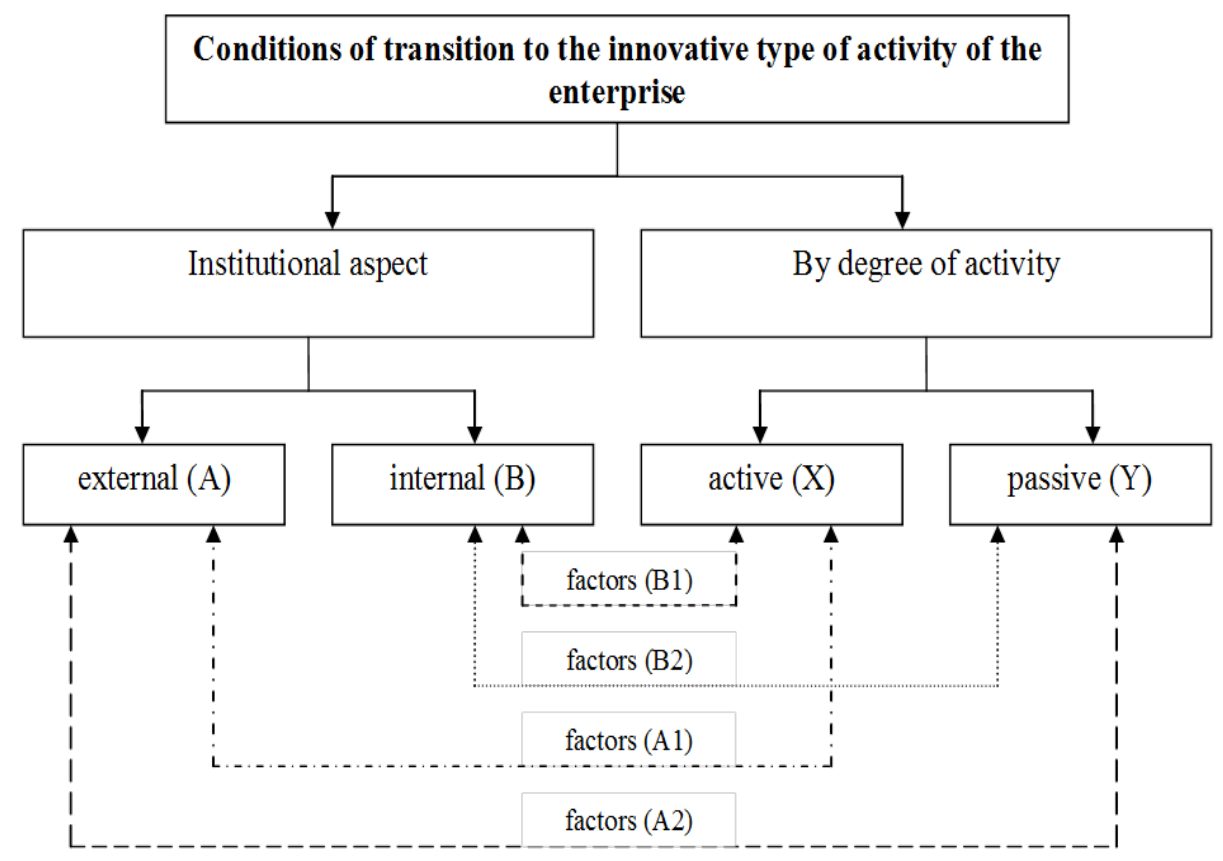

Fig. 1. Types of factors of innovative support of the enterprise. 


\section{Results}

Practical application of the proposed value will make it possible to carry out a comparative assessment of various economic entities according to their possibility (probability) and the potential for transition to an innovative type of activity. This opportunity will allow investors to reduce investment risks and make more informed decisions when choosing an investment object in conditions of increased demand from economic entities to attract external financial resources. For convenience of practical application of the formed approach, the probability of implementing innovative transformations of an economic entity is presented in the form of the following amount:

$$
\mathrm{W}_{\mathrm{INV}}=\frac{\sum_{\mathrm{i}=1} \mathrm{AX}_{\mathrm{i}}+\sum_{\mathrm{j}=1} \mathrm{AY}_{\mathrm{j}}+\sum_{\mathrm{n}=1} \mathrm{BX}_{\mathrm{n}}+\sum_{\mathrm{n}=1} \mathrm{BY}_{\mathrm{m}}}{\max \left(\sum_{\mathrm{i}=1} \mathrm{AX}_{\mathrm{i}}+\sum_{\mathrm{j}=1} \mathrm{AY}_{\mathrm{j}}+\sum_{\mathrm{n}=1} \mathrm{BX}_{\mathrm{n}}+\sum_{\mathrm{n}=1} \mathrm{BY}_{\mathrm{m}}\right)} * 100 \%
$$

where $\sum_{\mathrm{i}=1} \mathrm{AX}_{\mathrm{i}}, \sum_{\mathrm{j}=1} \mathrm{AY}_{\mathrm{j}}, \quad \sum_{\mathrm{n}=1} \mathrm{BX}_{\mathrm{n}}, \quad \sum_{\mathrm{n}=1} \mathrm{BY}_{\mathrm{m}}$ - total quantitative evaluation, respectively, external active, external passive, internal active, internal passive factors that form the conditions for the transition to the innovative type of enterprise activity;

$\max \left(\sum_{\mathrm{i}=1} \mathrm{AX}_{\mathrm{i}}+\sum_{\mathrm{j}=1} \mathrm{AY}_{\mathrm{j}}+\sum_{\mathrm{n}=1} \mathrm{BX}_{\mathrm{n}}+\sum_{\mathrm{n}=1} \mathrm{BY}_{\mathrm{m}}\right) \quad$ - the maximum quantitative assessment of the above factors.

In order to ensure the universality of the proposed approach, provided that its complexity is preserved, which consists in a comprehensive assessment of the sources of incentives for the innovation activity of an economic entity, the author proposes using the SWOT-analysis methodology with a numerical evaluation of factors having different forms of mapping (both qualitative and quantitative) application of a point system of the method of expert evaluations [4].

Taking into account the correlation links between various sources of innovative stimulus formation, the study selected the most significant factors based on the sufficiency principle (Table 1).

Table 1. The list of the most significant factors forming the conditions for the transition to an innovative type of enterprise activity.

\begin{tabular}{|c|c|}
\hline Classification type & Factors \\
\hline $\begin{array}{l}\text { External active } \\
\text { factors }\end{array}$ & $\begin{array}{l}\text { 1. Direct industry or targeted funding, state guarantees } \\
\text { 2. Industry tax policy } \\
\text { 3. Industry regulatory and legal regulation }\end{array}$ \\
\hline $\begin{array}{l}\text { External passive } \\
\text { factors }\end{array}$ & $\begin{array}{l}\text { 1. Level of competition in the market } \\
\text { 2. The degree of development of education in the direction of the } \\
\text { enterprise } \\
\text { 3. Innovation infrastructure } \\
\text { 4. Federal and regional legislative bases } \\
\text { 5. Degree of market openness to foreign capital }\end{array}$ \\
\hline \multirow{2}{*}{$\begin{array}{l}\text { Internal active } \\
\text { factors }\end{array}$} & $\begin{array}{l}\text { 1. The presence of strategic and tactical levels of planning of the } \\
\text { enterprise }\end{array}$ \\
\hline & $\begin{array}{l}\text { 2. Innovation orientation of the staff. } \\
\text { 3. Management qualification }\end{array}$ \\
\hline $\begin{array}{l}\text { Internal passive } \\
\text { factors }\end{array}$ & $\begin{array}{l}\text { 1. Production and technical base } \\
\text { 2. Ownership and organizational structure }\end{array}$ \\
\hline
\end{tabular}


On the one hand, from the author's point of view, the proposed list is a sufficient set of factors necessary for a comprehensive assessment of the company's innovation potential, taking into account the minimization of the cross-correlation effect, but in some cases the proposed list can be supplemented by separate factors also having a significant impact on subjects of the capacity analysis innovative development of an economic entity.

Based on the interrelationships of the above economic categories, the study proposes a classification of existing strategies for the development of the enterprise, depending on the degree of innovation use, which allowed to develop an algorithm for choosing the strategy of innovation and investment activity of the enterprise [5].

On the basis of research and analysis of modern economic literature, as well as the existing practice of development of Russian enterprises, different in terms of industry and ownership, the author identified and characterized the main types of strategies of economic entities, where the main classification characteristics are the degree of development of the enterprise, its sustainability and major risks Table 3).

Table 2. Type of enterprise development strategies.

\begin{tabular}{|c|c|c|c|}
\hline \multirow{2}{*}{ Characteristic } & \multicolumn{3}{|c|}{ Type of enterprise development strategies } \\
\hline & Regressive & Adaptive & Progressive \\
\hline $\begin{array}{l}\text { Development of } \\
\text { the enterprise }\end{array}$ & $\begin{array}{l}\text { Orientation to the state } \\
\text { dating, lack of } \\
\text { development and } \\
\text { innovations }\end{array}$ & $\begin{array}{l}\text { Simple reproduction, } \\
\text { imitating innovations }\end{array}$ & $\begin{array}{c}\text { Complex innovative } \\
\text { development }\end{array}$ \\
\hline $\begin{array}{l}\text { Ways of creation } \\
\text { of value added }\end{array}$ & Operational & Pointed investments & $\begin{array}{l}\text { Investment and } \\
\text { innovative }\end{array}$ \\
\hline $\begin{array}{l}\text { The relative size } \\
\text { of the created } \\
\text { value added }\end{array}$ & low & medium & high \\
\hline $\begin{array}{l}\text { Type of the } \\
\text { enterprises }\end{array}$ & $\begin{array}{l}\text { Uncompetitive, lost } \\
\text { position in the market }\end{array}$ & $\begin{array}{c}\text { Enterprises of } \\
\text { extraction and primary } \\
\text { processing of natural } \\
\text { resources }\end{array}$ & $\begin{array}{l}\text { Leaders in creation } \\
\text { or introduction of } \\
\text { high technologies }\end{array}$ \\
\hline $\begin{array}{l}\text { Financial stability } \\
\text { of the enterprise }\end{array}$ & $\begin{array}{c}\text { Financially unstable } \\
\text { enterprise }\end{array}$ & $\begin{array}{l}\text { Financially stable } \\
\text { enterprise in the short } \\
\text { or long term }\end{array}$ & $\begin{array}{c}\text { Economically stable } \\
\text { enterprise, balanced } \\
\text { stability }\end{array}$ \\
\hline $\begin{array}{c}\text { Relevant forms of } \\
\text { risk }\end{array}$ & Lack of borrowing & $\begin{array}{c}\text { Internal resistance to } \\
\text { transformation }\end{array}$ & Long-term risks \\
\hline
\end{tabular}

The classification made it possible to conclude that each development strategy of an economic entity has specific forms of risk and degrees of stability that determine the key features of the tactical and operational levels of enterprise management in the context of the need to attract investment of all types and forms. Thus, the strategy of an economic entity can be represented in the form of the following relationship:

$$
\mathrm{St}=f\left\{\frac{\partial \mathrm{G}}{\partial t}, \frac{\partial \mathrm{R}}{\partial t}\right\},
$$

where St - the strategy of the enterprise;

$$
\begin{aligned}
& \frac{\partial \mathrm{G}}{\partial t}-\text { - change in the degree of stability of the enterprise; } \\
& \frac{\partial \mathrm{R}}{\partial t}-\quad \text { - changing the risks of the enterprise. }
\end{aligned}
$$


On the other hand, the totality of endogenous processes in an enterprise should be considered taking into account the synergetic effect of transformations in economic systems of a level higher (industry, region, country).

Also, for the purpose of innovative breakthrough in the scale of the national economy, the transition from raw dependence to high-tech sectors of the national economy and import substitution of know-how facilities, the enterprise development strategy should be developed on the basis of introduction of both product and technological innovations and management innovations, volumes [6].

At the same time, the study noted that a positive innovation effect from the activities of enterprises can now also be achieved on the basis of strategies that actively use endogenous potential and aimed at modernizing a narrow section of the external market, and not just adapting their economic and economic activities to external conditions [7].

Proceeding from this, the author proposes to consider the process of selecting a strategy for managing the innovation and investment activity of an industrial enterprise in the form of a function of the parameters of its predictable stability and the total relative magnitude of the amount of risks of its activity in the context of the need to introduce product and technological and managerial innovations on the basis of attracting external investment taking into account the exogenous factors of the external innovation market. This dependence is presented in the following form:

$$
S t=\overbrace{f\left\{\frac{\partial t}{\partial t}, \frac{\partial R}{\partial t}, \frac{\partial \lambda V P V}{\partial t}\right\}}^{\text {finnov }}
$$

where $\mathrm{f}$ (innov) is the investment attractiveness of the enterprise;

$f($ exo) - a set of exogenous factors of the innovation market;

NPV - change of net present value of the enterprise.

On the basis of the revealed dependence, the author has developed and proposed an algorithm for determining the strategy for managing the innovation and investment activity of an industrial enterprise, which can also serve as an analytical tool when adjusting a previously defined strategy and clarifying the mission of the business entity.

\section{Discussion}

Developed author's approach to the selection of the strategy for managing the innovation and investment activity of the business entity allows the management and owners of the enterprise to determine the most acceptable innovative development strategy with a preliminary assessment of the forms and sizes of the necessary investment resources, with the possibility of adjusting the strategy at any stage of its practical implementation. The key feature of the author's algorithm is the choice of an innovative strategy based on the analysis of the parameters of the company's projected sustainability under given conditions of the need to introduce both product and technological innovations and management innovations by attracting external investments taking into account the exogenous factors of the external innovation market.

Strategic change of current economic and economic activity should be carried out on the basis of introduction of product, technological and managerial innovations and can be expressed both in the form of modernization of internal processes, modification of organizational structure by management of the managing subject. The emergence of positive economic efficiency from the implementation of the strategy of innovation and investment activity will be conditioned by a more complete use of own resources and 
capital through the systematic introduction of product, technological and managerial innovations based on the attraction of external and internal investment resources.

The developed model of investment-innovative activity of the enterprise will allow to increase the share of innovative products, to strengthen the innovative component of production, to intensify $\mathrm{R} \& \mathrm{D}$ with a positive growth of economic and social effects. At the same time, under the economic effect of innovation and investment reforms, the author suggests to understand the total amount of changes in budget efficiency, incomes of subjects of innovation and investment, scientific and technological progress and environmental conditions.

\section{Conclusion}

The study identified and characterized the main types of strategies of economic entities in terms of their innovation and investment development, which allowed to consider the process of selecting an enterprise development strategy as a function of the parameters of its predictable stability and the total relative magnitude of the amount of risks to its activities in the context of the need to introduce both food and technological, and managerial innovations on the basis of attraction of external investments taking into account exogenous factors of external inns innovational market.

Based on the revealed dependence, the author developed an algorithm for determining the strategy for managing the innovation and investment activity of an enterprise, the key feature of which is the choice of strategy based on a comprehensive analysis of the parameters of the company's projected sustainability.

\section{References}

1. V. Kankhva, B. Orlov, A. Vorobyeva, S. Belyaeva, R. Petrosyan, MATEC Web of Conferences 170, 01116 (2018) https://doi.org/10.1051/matecconf/201817001116

2. V. Dikareva, V.S. Kankhva, MATEC Web of Conferences 106, 08022 (2017) DOI: 10.1051/matecconf/20171060

3. A. Bolotin, V. Bakayev, Journal of Human Sport and Exercise 12, 405-413 (2017) pp., doi:10.14198/jhse.2017.122.17

4. F. Aggogeri, A. Borboni, R. Faglia, A. Merlo, N. Pellegrini, Applied Sciences (Switzerland) 7(2), 114 (2017)

5. A.S. Gorshkov, N.I. Vatin, Magazine of Civil Engineering 40(5), 5-19 (2013)

6. A. Bolotin, V. Bakayev, Journal of Human Sport and Exercise 12, 405-413 (2017) pp., doi:10.14198/jhse.2017.122.17

7. P. Ovchinnikov, A. Borodinecs, K. Strelets, Building and Environment 112, (2017), doi:10.1016/j.buildenv.2016.11.029 